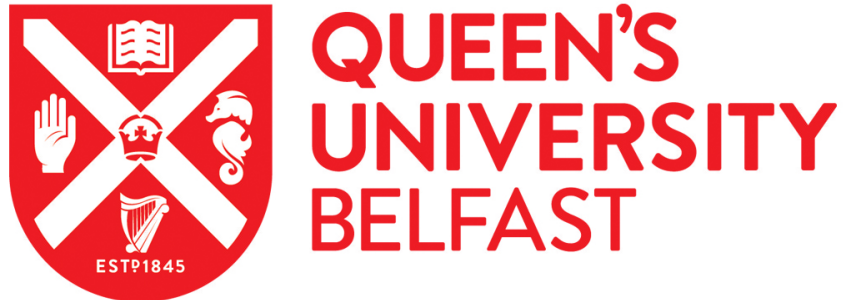

\section{Love Thy Neighbor? Relationships between Religion and Racial Intolerance in Europe.}

Doebler, S. (2015). Love Thy Neighbor? Relationships between Religion and Racial Intolerance in Europe. Politics and Religion. https://doi.org/10.1017/S1755048315000607

\section{Published in:}

Politics and Religion

\section{Document Version:}

Peer reviewed version

Queen's University Belfast - Research Portal:

Link to publication record in Queen's University Belfast Research Portal

Publisher rights

Copyright ( Religion and Politics Section of the American Political Science Association 2015

\section{General rights}

Copyright for the publications made accessible via the Queen's University Belfast Research Portal is retained by the author(s) and / or other copyright owners and it is a condition of accessing these publications that users recognise and abide by the legal requirements associated with these rights.

Take down policy

The Research Portal is Queen's institutional repository that provides access to Queen's research output. Every effort has been made to ensure that content in the Research Portal does not infringe any person's rights, or applicable UK laws. If you discover content in the Research Portal that you believe breaches copyright or violates any law, please contact openaccess@qub.ac.uk. 


\title{
Love Thy Neighbor? Relationships between Religion and Racial Intolerance in Europe
}

Stefanie Doebler

Queen’s University Belfast

\section{Accepted for Publication in: Politics \& Religion, 2015, Doi:10.1017/S1755048315000607}

The Politics and Religion Section of the American Political Science Association has the full copyright of this Article.

Address correspondence and reprint requests to: Stefanie Doebler, School of Geography, Archaeology and Palaeoecology, Queen’s University Belfast, Belfast, United Kingdom. E-mail: s.doebler@qub.ac.uk; stef.doebler@gmail.com

\begin{abstract}
:
This article examines relationships between religion and racial intolerance across 47 countries by applying multi-level modeling to European survey data and is the first in-depth analysis of moderation of these relationships by European national contexts. The analysis distinguishes a believing, belonging, and practice-dimension of religiosity. The results yield little evidence of a link between denominational belonging, religious practice, and racial intolerance. The religiosity dimension that matters most for racial intolerance in Europe is believing: believers in a traditional God and believers in a Spirit/Life Force are decidedly less likely, and fundamentalists are more likely than non-believers to be racially intolerant. National contexts also matter greatly: individuals living in Europe’s most religious countries, countries with legacies of ethnic-religious conflict and countries with low GDP are significantly more likely to be racially intolerant than those living in wealthier, secular and politically stable countries. This is especially the case for the religiously devout.
\end{abstract}




\section{Introduction}

Today’s modern societies are politically, religiously and ethnically diverse, thus a prevalence of intolerant attitudes poses a disturbance to the social harmony. Racial intolerance has been found to be a persistent problem in the United States (Goldman 2012; Johnson, Rowatt, and LaBouff 2010; Piston 2010; Valentino, Brader, and Jardina 2013) and in Europe (Billiet and De Witte 2008; Cutts, Ford, and Goodwin 2011; Ford 2008). Studies trying to understand racial intolerance and its covariates are thus of great interest to the scientific community and the public.

Religion has been found to be positively related to racial intolerance (Allport 1966; Bagley 1970; Johnson, Rowatt, and LaBouff 2010; Hall, Matz, and Wood 2010) and antiimmigrant attitudes (Scheepers, Gijsberts, and Hello 2002), despite the fact that the commandment to "love thy neighbor as thyself" is an essential teaching of the three major monotheistic religions in Europe (Anonymous 2007; Vaticana 2011). Political conflicts involving religious and ethnic identities have long been a part of European national histories. The ethno-religious conflicts throughout the 1990s and early 2000’s in South-Eastern European countries like the former Yugoslavia, Georgia, and Turkey are examples. But racial intolerance is prevalent in Western Europe, too. A recent rise in racist and anti-Muslim attacks in United Kingdom (Elgot 2013; Taylor and Siddique 2013), France (Ismail 2010; MacGuill 2013), and Germany (Spiegel 2014) and racial slurs uttered by some European media personalities and far-right politicians in the wake of the recent migrant boat tragedies in the Mediterranean have been widely reported in the media.

The study of relationships between religion and racial intolerance has a long tradition in the United States (Allport 1966; Glock and Stark 1966; 1969; Herek 1987). In Europe, academic interest in intolerance toward ethnic and racial out-groups has risen only recently. There are a few case studies looking at anti-immigrant and anti-Muslim attitudes in selected 
countries (Billiet and De Witte 2008; Ford 2008; Cutts, Ford, and Goodwin 2011; Frølund Thomsen 2012; Hodson, Sekulic, and Massey 1994) and a few large-scale cross-national comparisons (Coenders and Scheepers 2003; Eisinga, Billiet, and Felling 1999; Doebler 2013; Scheepers, Gijsberts, and Hello 2002; Schneider 2007; Strabac and Listhaug 2008). The vast majority focus on anti-immigrant attitudes, thus taking a Western European perspective. Yet, the Eastern half of Europe consists of sending, rather than receiving countries of immigrants. It is thus likely that intolerance toward ethnic out-groups in Eastern Europe manifests itself in relation to race and ethnicity, rather than immigration status. In Eastern Europe, attitudes toward immigrants are unlikely to be informed by past contacts. At the same time, countries like Romania, Bulgaria, Albania, Kosovo, Russia, and Turkey are ethnically diverse and have legacies of ethnic and religious conflict. Questions referring to race and ethnicity are therefore better suited than questions referring to immigrants to pick up intolerance toward ethnic out-groups in cross-national European comparisons.

This article focuses on racial intolerance and its relationship with religion in Europe, paying particular attention to the import of national contexts of religiousness, economic wealth and inequality, and recent histories of political instability and violence. Racial intolerance is defined here as a disinclination to accept members of a different race in one's close environment, for instance, as neighbors (Davies et al. 2011). Racial intolerance relates to the notion of prejudice, but while prejudice denotes generally negative attitudes toward an out-group (Augoustinos and Reynolds 2001), intolerance refers more directly to a rejection of its members.

This article seeks to add to the existing knowledge in three ways: first, by examining how three dimensions of religiosity — believing, belonging, and practice — are related to racial intolerance in Europe. The analysis applies multi-level modeling to survey data from the fourth wave of the European Values Study (2010). The European Values Study (EVS) 
covers attitudes in 47 countries and includes Russia, the Caucasus and the Balkan countries Albania, Azerbaijan, Kosovo, and Turkey.

Second, the analyses test hypotheses about the role of national contexts of religiousness, wealth and inequality, and the countries' average scores on an index of political stability and absence of violence over the years 1996 to 2008 (Kaufmann, Kraay, and Mastruzzi 2009) for the citizens' likelihood of being racially intolerant. Third, cross-level interactions test hypotheses about the national context as a moderator of relationships between religion and racial intolerance. There is a lack of European comparisons of religion and racial intolerance, particularly a scarcity of studies examining the role of national contexts and their interplay with individual-level religiosity. The literature thus far has analyzed contextual variables merely in terms of their main effects without acknowledging their role as moderators of relationships between individual religiosity and intolerance. The key questions of the analysis are: how are the three dimensions of religion related to racial intolerance in Europe? Does the national context, the country's mean level of religiosity, wealth (gross domestic product; GDP), income inequality, and political stability matter for individual attitudes toward people of a different race?

\section{Religion as a Three-Dimensional Phenomenon}

Religion is operationalized comprising of a believing, a belonging (denominational affiliation), and a practice dimension (church attendance, religious participation, prayer) (Davie 1990; Glendinning and Bruce 2006; Olson and Warber 2008). Previous studies (Doebler 2013; Huber 2007) found that the three dimensions of religiosity can be differently related to social attitudes.

Religious practice is measured through church attendance. Church attendance is an indicator of involvement in a moral community (Putnam and Campbell 2010; Stark and 
Bainbridge 1996). Moral community theory dates back to Émile Durkheim’s (1996 [1912]) notion of the church hosting a shared set of values. According to Stark and Bainbridge (1996) and Stark and Glock (1968), being integrated in church fosters pro-social attitudes, as churchgoers are more likely than others to internalize values of neighborly love and tolerance that are taught by Europe's three major monotheistic religions (Anonymous 2007; Parenti 1967; Vaticana 2011). Following the moral community argument (Putnam and Campbell 2010; Stark and Bainbridge 1996; Traunmüller 2011), church attendance can promote tolerance even if unaccompanied by believing, because the morals of the religious spill over to their less religious peers (Putnam and Campbell 2010). However, the findings in the literature are inconclusive. A number of early (Glock and Stark 1969; Johnson 1977) and contemporary studies (Guiso et al. 2003; Scheepers, Gijsberts, and Hello 2002) find church attendance to be positively related to out-group intolerance. Strabac and Listhaug $(2008,280)$ find a positive relationship in Eastern but not in Western Europe. Others find negative relationships: Meulemann and Billiet (2011) report a negative effect on ethnic threat perceptions in a majority of European countries, Billiet (1995) and Billiet and de Witte (2008) observe that Belgians who do not go to church regularly are more likely than those who do to express racial intolerance, and Coenders and Scheepers (2003, 332-333) report that across Europe non-churchgoers are more intolerant toward minorities. One likely reason why the findings are inconclusive is that churchgoers are exposed to different messages conveyed by clerics in church. Whether a cleric preaches neighborliness or intolerance likely influences churchgoers' attitudes. There are reports that religious leaders in regions such as the former Yugoslavia, Kosovo (Iveković 2002; Perica 2004), Greece (Mavrogordatos 2003), and Latvia (Mole 2011) have been preaching ethnic intolerance for years. With the surveys available on Europe, it is not possible to operationalize what messages the respondents have been exposed to in church. Teasing out such effects is beyond the scope of this article. We 
thus cannot hypothesize an overall (positive or negative) relationship between racial intolerance and church attendance. The relationship likely depends on the context.

The believing dimension is measured via different God-beliefs and fundamentalism. The literature thus far found different ways of religious believing and the content of different religious beliefs to be differently related to intolerance of out-groups (Djupe 2015). The study of relationships between believing and tolerance dates back to Allport and Ross’ (1967) work on (intrinsic vs. extrinsic) religious orientations and fundamentalism.

Allport and Ross (1967) found that among both the extrinsically and the intrinsically oriented, orthodox and fundamentalist believers were more likely to be racially prejudiced than less orthodox believers. Allport and Ross' work on religious orientations and prejudice has inspired numerous studies in psychology (Kirkpatrick 1993; Tiliopoulos et al. 2006).

Studies in the tradition of modernization theory (Inglehart and Welzel 2005; Norris and Inglehart 2004) found modern-individualized-, but not traditional religious beliefs to be associated with more tolerance. In addition, Froese and colleagues (Froese and Bader 2008; Froese, Bader, and Smith 2008) report that belief in a wrathful God, as opposed to a loving God, has negative effects on tolerance and trust. The idea behind this is that having internalized the notion of an unkind, punitive God is associated with exclusiveness and closed-mindedness and may thus foster out-group intolerance. The EVS distinguishes between belief in a personal God and belief in a Spirit/Life Force. The former accords with traditional (Christian and Islamic) religious doctrines, the latter departs from these doctrines and is more diffuse and open to alternative spiritual beliefs. Belief in a Spirit/Life Force is therefore more modern and individualized (Pollack and Pickel 2007). Both beliefs are hypothesized here to be negatively related to racial intolerance: 
H1: Traditional belief in a personal God and modern individualized belief in a Spirit/Life Force are both negatively related to racial intolerance.

It is important to distinguish non-fundamentalist from fundamentalist believing, as fundamentalism is a key predictor of intolerance toward religious, ethnic, and cultural outgroups (Altemeyer and Hunsberger 1992; Eisinga, Konig, and Scheepers 1995; Glock and Stark 1966; Laythe et al. 2002). Fundamentalism is defined here as an exclusive truth-claim of one religion over others, expressed by the statement "there is only one true religion." 1 This follows a convention in the literature (Kirkpatrick 1993; Leeming, Madden, and Stanton 2010).

Fundamentalism was found by studies in psychology to be closely related to closedmindedness and intolerance toward cultural and racial out-groups (Allport and Ross 1967; Altemeyer and Hunsberger 1992). It is thus plausible to hypothesize that:

H2: Fundamentalism is positively related to racial intolerance.

Regarding religious belonging, the analysis distinguishes between four religious traditions, Catholic, Protestant, Orthodox, and Islam. Denominational membership is, among other things, a marker of group-identification (Kunovich and Hodson 1999; Tajfel 1974). Social identity theorists argue that out-group rejection is an important aspect of in-group identification. According to the theory, in-group identification is achieved by distancing the self from out-groups, the "us" from the "them” (Tajfel and Turner 1979). Thus, people who strongly identify with a religion might endorse a stronger sense of social distance toward outgroups and therefore be more intolerant toward them than non-members or people who identify only casually. However, since the scriptures of Europe’s three major religions 
emphasize values of neighborly love and tolerance, it can just as plausibly be argued that members of religious denominations are no different from, or are even more tolerant than non-members. The literature so far is inconclusive. Some found Evangelical Protestants in the United States to be more intolerant than mainline Protestants, Catholics, and Jews (Beatty and Walter 1984; Burdette, Ellison, and Hill 2005; Froese, Bader, and Smith 2008), others found Muslims to be more intolerant toward deviant life styles (Inglehart and Norris 2003). These findings have not sufficiently been replicated in Europe. It can be hypothesized that:

H3: Across Europe as a whole Catholics, Protestants, Orthodox, Muslims and those without a religious affiliation do not differ significantly in their likelihood of being racially intolerant.

However, as with religious practice and believing, the relationship between religious belonging and racial intolerance is likely to vary between different national contexts. Thus, a main aim of this article is to tease out the import of the national context.

\section{The Import of the National Context}

The role of the national context for racial intolerance is under-researched. Several studies have analyzed relationships between countries’ levels of wealth, income inequality, religiosity and public attitudes toward democracy (Norris and Inglehart 2004; Inglehart and Welzel 2005), and social trust (Delhey and Dragolov 2013; Uslaner 2008), but there is a lack of studies focusing on out-group intolerance, racial intolerance in particular. Yet, some of the literature (Inglehart and Welzel 2005; Norris and Inglehart 2004) suggests that religion might be more salient in poorer countries with legacies of political instability and violence. Its relationship with racial intolerance is thus likely to differ depending on the national context. 
The literature on religious contexts is mostly based on the moral community hypothesis. Studies in this tradition assume that people living in highly religious contexts share religious morals (Stark and Bainbridge 1996; Traunmüller 2011). Social capital theorists stress that religious communities instill pro-social values such as good neighborliness in their members (Putnam and Campbell 2010; Traunmüller 2011). However, Putnam and Campbell also found members of religious communities to be less tolerant toward out-groups than people living in less religious communities. Furthermore, in Europe, the countries with the highest overall levels of religiosity are all located in the South- and South-East. The majority have histories of ethno-religious violence and ethnicity has traditionally been linked to religion in this region (Bieber and Daskalovski 2003; Waal 2004). It is thus plausible to expect that in Europe high levels of religiosity of countries are associated with higher levels of racial intolerance.

It is important to add that the South-eastern European countries also have poverty and high inequality in common. Thus, higher levels of racial intolerance in these countries may well be due to factors other than religion. This will be tested below. Since the general argument here is that religiosity is beneficial to tolerance toward minorities, the author hypothesizes that:

H4: When holding country-level wealth and legacies of political instability constant, a country's average level of religiosity is negatively related to its citizens’ levels of racial intolerance.

Modernization theory emphasizes the role of wealth and security in promoting value change from traditionalist, authoritarian values toward liberal values of self-expression and tolerance of diversity (Inglehart and Welzel 2005; Norris and Inglehart 2004). In highly developed 
countries with high levels of political stability, religion and traditionalism are on the decline, while liberal values and tolerance are rising. A similar argument is made by Wilkinson and Picket (2010) and Uslaner (2008) regarding the effect of income inequality. They claim that high income-inequality is related to a higher prevalence of mistrust and anti-social attitudes. It is thus expected that:

H5: People living in wealthy countries with high per capita GDP, countries with high levels of political stability and countries with (relatively) low income inequality are less likely to be racially intolerant than people living in poorer, politically unstable countries, and countries with high inequality.

Negative effects of country-level wealth (Adamczyk and Pitt 2009; Akker, Ploeg, and Scheepers 2013; Schneider 2007), political stability and good governance (Guiso, Sapienza, and Zingales 2003; Rothstein and Uslaner 2005) on out-group intolerance were confirmed by some authors. However, the relationships with religion have not sufficiently been examined yet. Contexts of wealth and political instability can affect people's tolerance toward outgroups not only directly, but also indirectly by moderating the effect of individual religiosity.

Inglehart and Welzel (2005) suggest that religion has more influence on attitudes in poorer than in wealthier countries. The mechanism is that religion in poorer settings can cater to human needs for safety and security while at the same time leading to a more closedminded, rigid mindset. At the same time, identity theory (Quillian 1995; Tajfel 1974) suggests that (religious) identities may become more closely related to anti-out-group attitudes in contexts that create a perceived threat to the group. Low wealth, perceptions of instability, and high inequality are all factors that may enhance such threat perceptions. One may thus expect that: 
H6: Individual religiosity is positively related to racial intolerance in poorer countries, countries with legacies of political instability and violence and countries with high levels of income inequality. In wealthy countries with high levels of political stability and in countries with moderate to low inequality, individual religiosity is unrelated to racial intolerance.

The moderating effect of the national context on relationships between religiosity and racial intolerance, as hypothesized in H6, is tested via cross-level interactions.

\section{Data and Methods}

The analysis uses data from the fourth wave of the European Values Study (2010). The EVS comprises $N=67,786$ individuals living in 47 European countries and is the survey with the most comprehensive coverage of Europe to date. The data are representative samples of the countries' adult populations of 16 years and older and were collected in each country via multi-stage random probability sampling. The net sample size is $1,000-1,500$ respondents per country. Because of Eastern Germany’s communist past and the resulting cultural differences between the two parts of Germany, Eastern and Western Germany are treated as separate entities.

\section{Variables}

Religious practice is measured by frequency of church attendance. Importance of religion (“how important is religion in your life?”) was included as a general measure of devoutness. It is important to include a measure of devoutness other than church attendance in order to capture those who are religious but do not go to church or mosque regularly. Across the pooled EVS data, 58\% of respondents who do not go to church still consider themselves 
religious. Meulemann and Billiet (2011) pointed out that Muslim women tend to attend mosque less often than men but are equally religious on other variables. The analysis should capture these respondents, too.

Believing is operationalized via three types of belief in God: traditional belief in a personal God, belief in a Spirit/Life Force ${ }^{2}$ as a fuzzy God-belief (Voas 2009) that is often associated with modernization and individualization and fundamentalism. Fundamentalism is operationalized via the statement "there is only one true religion."

As measures of religious belonging four dummy variables for the respondent's denomination — Catholic, Protestant, Orthodox, and Muslim are included and having no affiliation is the reference category. The EVS does not contain enough Jews and members of other religious minorities to enable meaningful comparisons. Therefore, these denominations were summarized into a category “other denomination” and included in the models.

\section{Context Measures}

The following context-variables were included: As a measure of country-level religiosity, the mean importance of religion per country was aggregated from the EVS-data. The countries' wealth was operationalized via their GDP per capita (International Monetary Fund 2007). GDP was log-transformed to adjust for its skewed distribution.

The countries’ recent history of political instability and violence was operationalized via the World Bank’s “Index of Political Stability and Absence of Violence” (Kaufmann, Kraay, and Mastruzzi 2009). The models include the mean score over the years 1996 to 2008, capturing occurrences of political instability and violence over a 12-year period. Ethnoreligious conflicts and tensions are explicitly included in this index (Kaufmann, Kraay, and Mastruzzi 2009, 60, 67). 
As a measure of income inequality, the countries’ Gini coefficients (International Monetary Fund 2007) were included. The coding and scaling of all variables is specified in Table 1.

\section{Controls}

The following controls were included: education (dummies: (1) respondent has tertiary (postsecondary) education, (2) respondent has above primary, below tertiary education), whether the respondent has experienced unemployment of three months or more, the respondent's age, sex (male as the reference category) and self-description as right-wing on a left-right scale.

Last, because there is a literature discussing the effect of the presence of immigrants in a country and contact opportunities on out-group attitudes (group-threat versus contact theory) (Coenders and Scheepers 2003; Emerson, Kimbro, and Yancey 2002; Quillian 1995; Pettigrew 1998; Wagner et al. 2006), the models control for the countries’ net migration rates. The net migration rate was obtained from the Central Intelligence Agency World Factbook (Central Intelligence Agency 2008). This is done to test whether the other contextual variables in the models have significant effects on their own when holding the net migration rate constant. Table 1 lists the descriptive statistics of the variables used in the multilevel model.

\section{Strategy}

The analysis compares relationships between religion and racial intolerance across Europe. Particular attention is paid to the import of national contexts. A multi-level analysis is therefore the appropriate approach (Hox 2010; Snijders and Bosker 1999). Because the 
dependent variable is binary, multilevel logistic regressions are carried out using the software package STATA 13.

\section{Analyses}

The random intercepts model has the following equation:

$$
\begin{aligned}
& \log \left[\frac{\mathrm{pij}}{1-\mathrm{pij}}\right]=\beta 0 \mathrm{j} \text { cons }+\beta 1 \text { Catholic }+\beta 2 \text { Protestantij }+\beta 3 \text { Orthodoxij }+ \\
& \beta 4 \text { Muslimij }+\beta 5 \text { Church Attendanceij }+\beta 6 \text { Importance of Religion }+ \\
& \beta 7 \text { Belief: Personal God }+\beta 8 \text { Belief: Spirit or Life Force }+ \\
& \beta 9 \text { Fundamentalism }+\beta 10 \text { Sex Female }+\beta 11 \text { Educationij }+ \\
& \beta 12 \text { Unemploymentij }+\beta 13 \text { Ageij }+\beta 14 \text { Strong Leaderij }+ \\
& \beta 15 \text { Country Mean Importance of Religion } \mathrm{j}+\beta 16 \text { GDP } \mathrm{j}+ \\
& \beta 17 \text { Political Stabilityj }+\beta 18 \text { bGini Coefficient }+ \\
& \beta 19 \text { Net Migration Rate }+\mathrm{u} 0 \mathrm{j}
\end{aligned}
$$

In a second step, cross-level interactions between the individual-level religion variables and the context variables are introduced.

When working with large-scale surveys, the analysis has to deal with missing values: of the 67,786 respondents in the dataset 5,689 have missing values on one or more of the variables of interest. Thus, a missing-data analysis testing whether missingness at random (MAR) can be assumed (Enders 2010, 13) was carried out. All models were then run in two sets, first as a complete case analysis and second applying multiple imputations using chained equations in STATA. The imputation model includes income, subjective health and lifesatisfaction as auxiliary variables. Thirty imputed datasets were created and the random intercepts models run across the imputed data. An imputation report is supplied in the online Appendix (Table A2). All models were tested for outliers and multi-collinearity diagnostics were carried out for all variables (supplied in the online Appendix, Table A3). The Cook's 
distance-values of the following countries indicted that they are influential outliers: Azerbaijan, Kosovo, and Macedonia. In order to adjust the models for these three outliers, thus achieving unbiased results while still preserving the statistical power, the intercept was adjusted for these outliers and dummies included for each, following Van der Meer, Grotenhuis and Pelzer's (2010) strategy.

\section{Results}

Table 2 gives the cross-country percentages of religious and non-religious respondents who expressed racial intolerance. The countries are ordered by percentage (countries with the lowest percentages appear at the top).

Table 2 reveals two findings. First, racial intolerance is the least prevalent among both the religious and the non-religious in Western Europe and the most prevalent in South-eastern Europe, particularly in Albania, Azerbaijan, Northern Cyprus, Turkey, and Kosovo. The context variables hypothesized above are thus plausible candidates for explaining the variation, as the countries with the highest levels of racial intolerance are also among the least wealthy, have low scores of political stability, and above average levels of overall religiosity. It is clear that religious people are more similar to their fellow citizens than they are to fellow believers across countries, thus it is important to test for contextual effects. Second, the percentages suggest that there is indeed a positive relationship between individual religiosity and racial intolerance in a majority of countries.

\section{The Multilevel Models}

An empty model, containing only the constant and the random intercept ${ }^{3}$ yielded a betweencountry variance in levels of racial intolerance of 0.792 . Thus $19 \%$ of the total variability of racial intolerance in Europe is explained by unobserved country-level traits. Table 3 contains 
the results of the binary logistic multi-level model, including individual-level religion, the contextual measures and controls.

The model shows that of the individual-level religion measures it is the believing dimension that is really relevant for racial intolerance. As hypothesized in $\mathrm{H} 1$ and $\mathrm{H} 2$, both belief in a personal God and belief in a Spirit/Life Force are strongly and statistically significantly negatively and fundamentalism strongly positively related to racial intolerance. As to religious belonging, members of the four denominations do not differ significantly from non-members in their likelihood of being racially intolerant when controlling for the respondent's education and socio-economic status. The findings thus support H3. Furthermore, across Europe as a whole, church attendance is not at all, and finding religion important only weakly and statistically positively related to racial intolerance. It is clearly the believing dimension that shows the strongest and most robust relationships with racial intolerance. Both traditional God-belief and modern individualized belief in a Spirit/Life Force are strongly negatively related to racial intolerance. Belief in the fundamentalist religious truth-claim, on the other hand, is strongly positively related to racial intolerance. When the model coefficients are expressed as odds-ratios, it becomes clear that controlling for the other variables in the model, believers in a personal God are $17 \%$ less likely and believers in a Spirit/Life Force 29\% less likely than non-believers (the reference category) to be racially intolerant. Those who believe in the fundamentalist truth-claim are 35\% more likely than those who do not to be racially intolerant.

In summary, H1, H2, and H3 are supported by the results. Non-fundamentalist religious believing seems to indeed be informed by religious values of neighborliness and toleration that are included in the teachings of Europe's major denominations. Fundamentalist believing, on the other hand seems to be informed by a mindset of religious intolerance (intolerance toward the idea that other religions might also claim some legitimacy). The result 
of the model indicates that fundamentalist individuals are also vulnerable to racial intolerance. The controls sex, age, experiences of long-term unemployment and being rightwing are all strongly significantly positively related to racial intolerance. However, the statistical effects of all individual-level religiosity measures vary significantly across countries, thus the next step is taking a closer look at the national contexts hypothesized to influence the relationships.

Looking at the coefficients of the country-level variables in Table 4 we see that only two, the countries' mean importance of religion and per capita GDP, are statistically significant.

Income inequality, political stability, and the net migration rate all have significant effects when included on their own, but lose their statistical significance once country-level religiosity and per capita GDP are included. H5 is thus only partly supported by the data.

The relationship between country-level religiosity and racial intolerance is positive. People living in countries with more religious populations are more likely to be racially intolerant than people living in secularized countries where religion does not provide a strong social context. Even when controlling for the fact that many of Europe's highly religious countries also have a legacy of political instability and violence, the effect of country-level religiosity remains strong and statistically significant. Thus, at least in Europe, the good neighborliness, which is often theorized to be instilled by the moral community, does not extend to racial out-groups. H4 thus has to be rejected by the analysis.

The finding makes clear that individual-level and macro-level religiosity should not be conflated. On the individual-level, religious devoutness (finding religion important and church attendance) hardly makes a statistical difference to racial intolerance, but as a context, at least in Europe, the moral community appears to have a dark side. Figure 1 visualizes the 
relationship: countries with high mean-religiosity also tend to have populations with higher levels of racial intolerance.

Turkey, Armenia, Azerbaijan, Kosovo, Macedonia, and Georgia are among both the most religious and the least politically stable countries in Europe — and among the highestscoring in racial intolerance. Although the political climate in most of these countries has stabilized since the 1990s, high religious identification still seems to be strongly linked to legacies of ethnic — and religious tensions. Note that although the multi-collinearity tests (online Appendix, Table A3) were satisfactory, the model cannot avoid some degree of correlation of its country-level variables, given that the number of countries is limited. The Country mean importance of religion and "Political stability and absence of violence" are moderately correlated (Pearson's $r=-0.5$ ), due to overlaps at the high ends of the two scales.

As to country-level wealth, the relationship is as hypothesized: countries with high levels of wealth (GDP) also have more tolerant populations. Both findings are in line with modernization theory (Inglehart and Welzel 2005; Norris and Inglehart 2004): Populations of modernized, wealthier, and secularized countries are more tolerant toward racial out-groups than populations of less developed and more religious/traditionalist countries. H5 is thus partly supported by the results. When it comes to racial tolerance, the countries' levels of modernization, wealth and secularism are more influential than the legacy of political stability, income inequality and migration rates. Note, however that when included on their own both political instability and income inequality are significantly related to higher levels of racial intolerance.

As a last step, cross-level interactions were carried out between individual-level religiosity (belief in a personal God, belief in a Spirit/Life Force, fundamentalism, importance of religion and church attendance $)^{4}$ and the country-level variables. Each crosslevel interaction was included in a separate step of the model. 
The aim is to test whether the relationships between religion and racial intolerance are moderated by the country-level traits hypothesized in $\mathrm{H6}^{5}$. Table 4 shows the cross-level interactions. The models were run including all controls.

Table 4 shows a consistent pattern of moderation of individual religiosity by countrylevel variables. Finding religion important and attending church regularly are more strongly related to racial intolerance in countries that are highly religious, have legacies of political instability and violence, low GDP, and low net migration rates. The latter finding is likely related to fewer contact opportunities with racial out-groups, as theorized by contact theory (Emerson, Kimbro, and Yancey 2002; Pettigrew 1998; Quillian 1995).

Figure 2 visualizes these micro-macro relationships at the example of finding religion important. The figure combines four cross-level interaction plots between importance of religion and the countries’ aggregate-levels of religiosity, mean "political stability and absence of violence 1996-2008”-scores, GDP per capita, and the countries’ net migration rates.

The plots show the average marginal effect of importance of religion along the scales of the four country-level variables with $95 \%$ confidence intervals. The $y$-axes display the change in the likelihood of expressing racial intolerance for a one-unit change in importance of religion at each point on the scales of the country-level variables. We see clearly from Figure 2 that the likelihood of religiously devout people of expressing racial intolerance increases with increasing levels of aggregate country-religiosity, political instability, and poverty (low GDP). In countries with low levels of religiosity, high levels of wealth, political stability, and high net migration rates the coefficient of importance of religion is even negative, although the effect is only modest and the confidence intervals indicate that the true value might be close to zero in these countries. 
These patterns lend further support to modernization theory (Inglehart and Welzel 2005; Norris and Inglehart 2004). The countries’ levels of income inequality, as theorized by Wilkinson and Picket (2010), do not significantly moderate any of the religiosity effects. H6 is thus partly supported by the results.

Interestingly, the interactions between the country-level predictors and religious believing are consistently weaker than the interactions with church attendance and importance of religion. The countries' aggregate-levels of religiosity and their levels of income inequality and migration do not moderate the statistical effects of religious believing at all. Country GDP shows a moderating effect only on belief in a Spirit/Life Force and on fundamentalism, but not on belief in a Personal God and the mean political stability 19962008-score moderates only fundamentalism. The direction of the relationships is consistent with the other religion measures.

The negative effects of non-fundamentalist God-beliefs are strong across Europe as a whole and highly robust across the majority of countries.

In summary, of the three dimensions of religion, it is the believing dimension that matters most for racial tolerance across countries. Non-fundamentalist individual believing is strongly negatively related to racial intolerance in Europe. The relationship is reversed in a small group of South-Eastern European countries that have low levels of economic development paired with high levels of aggregate religiosity, political instability and legacies of ethno-religious violence.

\section{Discussion and Conclusion}

The analyses presented in this article tried to examine how three dimensions of religiosity, believing, belonging and practice are related to racial intolerance in Europe and how religious, economic and political national contexts influence the relationship. The results of 
the multi-level models confirm some of the literature (Inlehart and Welzel 2005; Norris and Inglehart 2004; Scheepers, Gijsberts, and Hello 2002), but also add new insights to the body of knowledge on religion and racial intolerance. The main findings are that of the three dimensions of religion, believing exhibits the strongest relationships with racial intolerance, differences across religious traditions are largely accounted for by other variables and religious practice (church attendance) is statistically unrelated to racial intolerance in most European countries. The findings indicate that across Europe the private contemplation of religious beliefs and values is more influential for racial tolerance. Non-fundamentalist believing is strongly negatively related to racial intolerance, and the relationship is highly robust across countries.

The national context matters greatly for the likelihood of individuals tolerating racial out-groups: the countries’ wealth (low GDP), aggregate levels of religiosity, and legacies of political instability and violence are strongly related to the populations’ levels of racial intolerance and moderate the effect of individual religiosity. Devoutness and religious practice are positively related to racial intolerance in (relatively) poor and politically unstable, but not in wealthy European countries that have a long tradition of democratic stability. The pure effect of aggregate religiosity on racial intolerance is difficult to ascertain because in Europe there is an overlap between high levels of country-religiosity, high levels of political instability, and historical legacies of ethnic and/or religious violence. The main cluster that stands out consists of South-eastern European countries: Armenia, Albania, Azerbaijan, Kosovo, Macedonia, Georgia, and Turkey. The analysis found strong associations between these contexts and racial intolerance, but causal assumptions cannot easily be made based on cross-sectional data. Future longitudinal analyses of relationships between religion and out-group intolerance in these countries would add greatly to the existing knowledge. 
The finding merits a renewed discussion of the moral community hypothesis: the literature so far (Putnam and Campbell 2010; Stark and Bainbridge 1996; Traunmüller 2011) has been somewhat optimistic about the civic benefits of religious contexts. However, moral community theory tends to underestimate the dark side of the moral community: The results of this article demonstrate that indicators of strong moral communities that have been found to foster good neighborliness (Putnam and Campbell 2010) and prevent crime in the United States (Stark and Bainbridge 1996) are positively related to racial intolerance in several South-Eastern European countries. High overall levels of religiosity combined with historical legacies of ethnic conflict (Anzulovic 1999; Waal 2004) and economic deprivation can create dysfunctional moral communities that foster the spread of anti-social attitudes not only among the religious, but also among non-religious citizens. The link between dysfunctional moral communities, religion, and intolerance in Eastern and South-Eastern Europe has not sufficiently been examined yet. This is a gap in the literature. In particular, what are possible mechanisms that create persistent links between religion and intolerance in some countries but not in others? Future work could contribute greatly to the existing knowledge by providing further in-depth analyses of the relationship in this region. The results of this paper found important relationships between racial intolerance and religion across Europe and highlighted national contexts that are influential for these relationships. They are thus a first step in this direction.

\section{Notes}

1. The statement "there is only one true religion" is dummy-coded against the reference “other religions have some basic truths as well” and “all great world religions have some truths to offer.” 
2. The RMSEA value of the multi-group (item-response-) confirmatory factor analysis (Embretson and Reise 2000) of the five-item scale was 0.09 when all five ethnic-religious groups of the battery were included. Excluding items with low factor loadings did not yield a better model fit, the RMSEA remained over 0.07 . The literature names a value of 0.05 or lowers as a requirement for acceptable model fit (see Brown 2006, 84). The result suggests that not all five items can be assumed to have the same meaning across countries. Partial scalar invariance, a necessary condition to be allowed to compare the results across countries (Meulemann and Billiet 2011) was not achieved. Especially intolerance of immigrants, the measure chosen most often in the European literature does not discriminate as well as not wanting a person of a different race as a neighbor in sending countries of immigrants like Turkey, Azerbaijan, Lithuania, Albania, Moldova, and Ukraine. Tables containing the factor loadings and intercepts can be obtained from the author upon request.

3. Both types of belief in God are categories of "Which of these statements comes closest to your beliefs? — there is a personal God — there is some sort of Spirit or Life Force — I don’t know what to think — I don’t really think there is any sort of God, Spirit or Life/Force.” The two answers “I don't know what to think” and “I don’t really believe there is any sort of God, Spirit or Life Force” were collapsed to form the reference category because there were not enough cases in all countries to include the atheist category in the model.

4. The Intercepts of the models are allowed to vary randomly across countries. For reasons of space economy the empty model is not presented in Table 3.

5. Since membership in religious denominations is highly clustered by country, it is not feasible to analyze moderation of denominational belonging by the national context using cross-level interactions. It is known that Orthodox and Muslim denominational membership is clustered in Eastern- and South-Eastern European countries. 


\section{References}

Adamczyk, Amy, and Cassady Pitt. 2009. "Shaping Attitudes about Homosexuality: The Role of Religion and Cultural Context.” Social Science Research 38:338-351.

Akker, Hanneke van den, Rozemarijn van der Ploeg, and Peer Scheepers. 2013. "Disapproval of Homosexuality: Comparative Research on Individual and National Determinants of Disapproval of Homosexuality in 20 European Countries.” International Journal of Public Opinion Research 25:64-86.

Allport, G. W. 1966. “The Religious Context of Prejudice.” Journal for the Scientific Study of Religion 5:447-457.

Allport, G. W., and J. M. Ross. 1967. "Personal Religious Orientation and Prejudice.” Journal of Personality and Social Psychology 5:432-443.

Altemeyer, Bob, and Bruce Hunsberger. 1992. “Authoritarianism, Religious

Fundamentalism, Quest, and Prejudice.” International Journal for the Psychology of Religion 2:113-133.

Anonymous. 2007. “Open Letter to His Holiness Pope Benedict. 13 October 2007.” http://www.acommonword.com/a-common-word-and-christian-muslim-dialogue .

Anzulovic, Branimir. 1999. Heavenly Serbia. From Myth to Genocide. New York, NY: New York University Press.

Augoustinos, Martha, and Katherine Jane Reynolds. 2001. Understanding Prejudice, Racism, and Social Conflict. London: Sage.

Bagley, C. 1970. "Relation of Religion and Racial Prejudice in Europe.” Journal for the Scientific Study of Religion 9:219-225.

Beatty, Kathleen, and Oliver Walter. 1984. "Religious Preference and Practice: Reevaluating Their Impact on Political Tolerance.” Public Opinion Quarterly 48:318-329. 
Bieber, Florian, and Zidas Daskalovski. 2003. Understanding the War in Kosovo. London: Routledge.

Billiet, Jaak. 1995. “Church Involvement, Individualism, and Ethnic Prejudice among Flemish Roman Catholics: New Evidence of a Moderating Effect.” Journal for the Scientific Study of Religion 34:224-233.

Billiet, Jaak, and Hans De Witte. 2008. "Everyday Racism as Predictor of Political Racism in Flemish Belgium.” Journal of Social Issues 64:253-267.

Brown, Timothy A. 2006. Confirmatory Factor Analysis for Applied Research. New York: The Guilford Press.

Burdette, A. M., C. G. Ellison, and T. D. Hill. 2005. “Conservative Protestantism and Tolerance toward Homosexuals: An Examination of Potential Mechanisms.” Sociological Inquiry 75:177-196.

Central Intelligence Agency. 2008. “The Central Intelligence Agency World Factbook 2008.” https://www.cia.gov/library/publications/resources/the-world-factbook/index.html. Coenders, Marcel, and Peer Scheepers. 2003. “The Effect of Education on Nationalism and Ethnic Exclusionism: An International Comparison.” Political Psychology 24: 313343.

Cutts, David, Robert Ford, and Matthew J. Goodwin. 2011. “Anti-Immigrant, Politically Disaffected or Still Racist after All? Examining the Attitudinal Drivers of Extreme Right Support in Britain in the 2009 European Elections.” European Journal of Political Research 50:418-440.

Davie, Grace. 1990. "Believing Without Belonging — Is This the Future of Religion in Britain?” Social Compass 37:455-469.

Davies, Kristin, Linda R. Tropp, Arthur Aron, Thomas F. Pettigrew, and Stephen C. Wright. 2011. “Cross-Group Friendships and Intergroup Attitudes: A Meta-Analytic Review.” 
Personality and Social Psychology Review 15(4):332-

51. Doi:10.1177/1088868311411103

Delhey, Jan and Georgi Dragolov. 2013. "Why Inequality Makes Europeans Less Happy:

The Role of Distrust, Status Anxiety, and Perceived Conflict.” European Sociological Review jct033. Doi: 10.1093/esr/jct033

Djupe, Paul. 2015. “Introduction” In Religion and Political Tolerance in America: Advances in the State of the Art. Philadelphia, PA: Temple University Press.

Doebler, Stefanie. 2013. "Relationships between Religion and Intolerance towards Muslims and Immigrants in Europe — A Multilevel Analysis.” Review of Religious Research.56:61-86.

Durkheim, Emile. 1996 [1912]. The Elementary Forms of Religious Life. New York, NY: The Free Press.

Eisinga, Rob, Jaak Billiet, and Albert Felling. 1999. “Christian Religion and Ethnic Prejudice in Cross-National Perspective - A Comparative Analysis of the Netherlands and Flanders (Belgium).” International Journal of Comparative Sociology 40:375-393. Eisinga, Rob, Ruben Konig, and Peer Scheepers. 1995. “Orthodox Religious Beliefs and Anti-Semitism: A Replication of Glock and Stark in the Netherlands.” Journal for the Scientific Study of Religion, 214-223.

Elgot, Jessica. 2013. “Women Targeted in Anti-Muslim Attacks, More than Half by Far Right Groups, Tell MAMA Report Says.” http://www.huffingtonpost.co.uk/ 2013/03/11/anti-muslim_n_2851282.html

Embretson, Susan E., and Steven P. Reise. 2000. Item Response Theory for Psychologists. New York, NY: Routledge. 
Emerson, Michael O., Rachel Tolbert Kimbro, and George Yancey. 2002. “Contact Theory Extended: The Effects of Prior Racial Contact on Current Social Ties.” Social Science Quarterly 83:745-761.

Enders, Craig K. 2010. Applied Missing Data Analysis. New York: Guilford Press.

European Values Study. 2010. “European Values Study 2008, 4th Wave, Integrated Dataset.” GESIS Data Archive, Cologne, Germany.

Ford, Robert. 2008. “Is Racial Prejudice Declining in Britain?” The British Journal of Sociology 59:609-636.

Froese, Paul, and Christopher Bader. 2008. “Unraveling Religious Worldviews: The Relationship between Images of God and Political Ideology in a Cross-Cultural Analysis.” Sociological Quarterly 49:689-718.

Froese, Paul, Christopher Bader, and Buster Smith. 2008. "Political Tolerance and God’s Wrath in the United States.” Sociology of Religion 69:29-44.

Frølund Thomsen, J. P. 2012. “How Does Intergroup Contact Generate Ethnic Tolerance? The Contact Hypothesis in a Scandinavian Context.” Scandinavian Political Studies 35:159-178.

Glendinning, Tony, and S. Bruce. 2006. "New Ways of Believing or Belonging: Is Religion Giving Way to Spirituality?” British Journal of Sociology 57:399-414.

Glock, Charles, and Rodney Stark. 1966. Christian Beliefs and Anti-Semitism. New York, NY: Harper \& Row.

Glock, Charles, and Rodney Stark. 1969. “Prejudice in the Churches.” In Prejudice U.S.A., eds. Glock, Charles, and Ellen Siegelman. New York, NY: Frederick A. Praeger.

Goldman, Seth K. 2012. "Effects of the 2008 Obama Presidential Campaign on White Racial Prejudice.” Public Opinion Quarterly 76:663-687. 
Guiso, Luigi, Paola Sapienza, and Luigi Zingales. 2003. “People’s Opium? Religion and Economic Attitudes.” Journal of Monetary Economics 50:225-282.

Hall, Deborah L., David C. Matz, and Wendy Wood. 2010. “Why Don’t We Practice What We Preach? A Meta-Analytic Review of Religious Racism.” Personality and Social Psychology Review 14:126-139.

Herek, Gregory M. 1987. "Religious Orientation and Prejudice: A Comparison of Racial and Sexual Attitudes.” Personality and Social Psychology Bulletin 13:34-44..

Hodson, Randy, Dusko Sekulic, and Garth Massey. 1994. "National Tolerance in the Former Yugoslavia.” American Journal of Sociology 99:1534-1558.

Hox, J. J. 2010. Multilevel Analysis: Techniques and Applications. London: Routledge. Huber, Stefan. 2007. “Are Religious Beliefs Relevant in Daily Life?” In Religion inside and Outside Traditional Institutions, ed. Streib, Heinz. Leiden: Brill, 209-230. International Monetary Fund. 2007. “IMF World Economic Outlook Database:” https://www.imf.org/external/pubs/ft/weo/2007/02/weodata/index.aspx . Inglehart, Ronald, and Pippa Norris. 2003. “The True Clash of Civilizations.” Foreign Policy 135:62-70.

Inglehart, Ronald, and Christian Welzel. 2005. Modernization, Cultural Change and Democracy. Cambridge: Cambridge University Press.

Ismail, Benjamin. 2010. "Ban the Burqa? France Votes Yes. http://www.meforum.org/2787/france-ban-the-burqa.

Iveković, Ivan. 2002. "Nationalism and the Political Use and Abuse of Religion: The Politicization of Orthodoxy, Catholicism and Islam in Yugoslav Successor States.” Social Compass 49:523-536.

Johnson, Doyle P. 1977. “Religious Commitment, Social Distance, and Authoritarianism.” Review of Religious Research 18(2):99-113. DOI: 10.2307/3509645 
Johnson, Megan K., Wade C. Rowatt, and Jordan LaBouff. 2010. “Priming Christian Religious Concepts Increases Racial Prejudice.” Social Psychological and Personality Science 1:119-126.

Kaufmann, Daniel, Aart Kraay, and Massimo Mastruzzi. 2009. “Governance Matters VIII: Aggregate and Individual Governance Indicators, 1996-2008.” http://ssrn.com/paper=1424591.

Kirkpatrick, Lee A. 1993. "Fundamentalism, Christian Orthodoxy, and Intrinsic Religious Orientation as Predictors of Discriminatory Attitudes.” Journal for the Scientific Study of Religion 32:256-268.

Kunovich, Robert M., and Randy Hodson. 1999. “Conflict, Religious Identity, and Ethnic Intolerance in Croatia.” Social Forces 78:643-668.

Laythe, Brian, Deborah G. Finkel, Robert G. Bringle, and Lee A. Kirkpatrick. 2002.

“Religious Fundamentalism as a Predictor of Prejudice: A Two-Component Model.” Journal for the Scientific Study of Religion 41:623-635.

Leeming, David A., Kathryn Madden, and Marlan Stanton. 2010. Encyclopedia of Psychology and Religion. New York, NY: Springer, 341-342.

MacGuill, Dan. 2013. “French Teen 'Attacked for Wearing Muslim Veil.’” http://www.thelocal.fr/20130813/teen-girl-attacked-near-paris-for-wearing-muslimveil.

Mavrogordatos, George. 2003. “Orthodoxy and Nationalism in the Greek Case.” West European Politics 26:117-136.

Meulemann, Baart and Jaak Billiet. 2011. "Religious Involvement: Its Relation to Values and Social Attitudes.” in Cross-Cultural Analysis: Methods and Applications. New York: Routledge. 
Mole, R. 2011. "Nationality and Sexuality: Homophobic Discourse and the 'National Threat' in Contemporary Latvia.” Nations and Nationalism 17:540-560.

Norris, Pippa, and Ronald Inglehart. 2004. Sacred and Secular. Religion and Politics Worldwide. Cambridge: Cambridge University Press.

Olson, Laura R., and Adam L. Warber. 2008. “Belonging, Behaving, and Believing Assessing the Role of Religion on Presidential Approval.” Political Research Quarterly 61:192-204.

Parenti, Michael. 1967. "Political Values and Religious Cultures: Jews, Catholics, and Protestants.” Journal for the Scientific Study of Religion 6:259-69.

Perica, Vjekoslav. 2004. Balkan Idols: Religion and Nationalism in Yugoslav States. Oxford: Oxford University Press.

Pettigrew, Thomas F. 1998. “Intergroup Contact Theory.” Annual Review of Psychology 49:65-85.

Piston, Spencer. 2010. “How Explicit Racial Prejudice Hurt Obama in the 2008 Election.” Political Behavior 32: 431-451.

Pollack, D., and Gert Pickel. 2007. "Religious Individualization or Secularization? Testing Hypotheses of Religious Change — The case of Eastern and Western Germany.” The British Journal of Sociology 58:603-632.

Putnam, Robert D., and David E. Campbell. 2010. American Grace. New York, NY: Simon \& Schuster.

Quillian, Lincoln. 1995. "Prejudice as a Response to Perceived Group Threat: Population Composition and Anti-Immigrant and Racial Prejudice in Europe.” American Sociological Review 60:586-611.

Rothstein, Bo, and Eric M. Uslaner. 2005. “All for All: Equality, Corruption, and Social Trust.” World Politics 58:41-72. 
Scheepers, Peer, Merove Gijsberts, and Evelyn Hello. 2002. "Religiosity and Prejudice against Ethnic Minorities in Europe: Cross-National Tests on a Controversial Relationship.” Review of Religious Research 43:242-265.

Schneider, Silke. 2007. “Anti-Immigrant Attitudes in Europe: Outgroup Size and Perceived Ethnic Threat.” European Sociological Review 24:53-67.

Snijders, T. A. B., and Roel J. Bosker. 1999. Multilevel Analysis: An Introduction to Basic and Advanced Multilevel Modeling. New York, NY: SAGE.

Spiegel. 2014. “Islamophobic Hate Groups Become More Prominent in Germany.” http://www.spiegel.de/international/germany/islamophobic-hate-groups-becomemore-prominent-in-germany-a-956801.html .

Stark, Rodney, and William Sims Bainbridge. 1996. Religion, Deviance, and Social Control. New York, NY: Routledge.

Stark, Rodney, and Charles Y. Glock. 1968. American Piety: The Nature of Religious Commitment. Los Angeles, CA: University of California Press.

Strabac, Zan, and Ola Listhaug. 2008. “Anti-Muslim Prejudice in Europe: A Multilevel Analysis of Survey Data from 30 Countries.” Social Science Research 37:268-286.

Tajfel, Henri. 1974. “Social Identity and Intergroup Behaviour.” Social Science Information 13:65-93.

Tajfel, Henri and John C. Turner. 1979. “An Integrative Theory of Intergroup Conflict.” Pp. 33-47 in The social psychology of intergroup relations, edited by W. G. Austin and S. Worchel. Monterey, CA: Brooks/Cole.

Taylor, Matthew, and Haroon Siddique. 2013. “Woolwich Murder: 200 Islamophobic Incidents since Lee Rigby’s Killing.” http://www.theguardian.com/uk/2013/may/28/ woolwich-murder-200-islamophobic-incidences. 
Tiliopoulos, Niko, Annemieke P. Bikker, Anthony P.M. Coxon, and Phillip K. Hawkin. 2006. “The Means and Ends of Religiosity: A Fresh Look at Gordon Allport’s Religious

Orientation Dimensions.” Personality and Individual Differences 42:1609-1620.

Traunmüller, Richard. 2011. "Moral Communities? Religion as a Source of Social Trust in a Multilevel Analysis of 97 German Regions.” European Sociological Review 27:346363.

Uslaner, Eric. 2008. “Trust as a Moral Value.” In The Handbook of Social Capital. Oxford: Oxford University Press, 101-120.

Valentino, Nicholas A., Ted Brader, and Ashley E. Jardina. 2013. “Immigration Opposition Among U.S. Whites: General Ethnocentrism or Media Priming of Attitudes About Latinos?” Political Psychology 34:149-166.

Van der Meer, Tom, Te Grotenhuis, and Ben Pelzer. 2010. “Influential Cases in Multilevel Modelling.” American Sociological Review 75:173-178.

Vaticana. 2011. Catechism of the Catholic Church. Citta del Vaticano: Libreria Editrice Vaticana.

Voas, D. 2009. “The Rise and Fall of Fuzzy Fidelity in Europe.” European Sociological Review 25(2):155-68. Doi: 10.1093/esr/jcn044

Waal, Thomas de. 2004. Black Garden: Armenia and Azerbaijan through Peace and War. New York, NY: New York University Press.

Wagner, Ulrich, Carina Wolf, Jost Stellmacher, and T. F. Pettigrew. 2006. "Prejudice and Minority Proportion: Contact instead of Threat Effects.” http://pub.unibielefeld.de/publication/2474993 .

Welch, M. R., D. Sikkink, E. Sartain, and C. Bond. 2004. “Trust in God and Trust in Man: The Ambivalent Role of Religion in Shaping Dimensions of Social Trust.” Journal for the Scientific Study of Religion 43:317-343. 
Wilkinson, Richard, and Kate Pickett. 2010. The Spirit Level: Why Equality Is Better for Everyone. London: Penguin. 
Table 1. Descriptive statistics for outcome variables

\begin{tabular}{|c|c|c|c|c|c|}
\hline $\begin{array}{l}\text { Continuous } \\
\text { Variable }\end{array}$ & Obs. & Mean & $\begin{array}{l}\text { Std. } \\
\text { Dev. }\end{array}$ & Min & Max \\
\hline $\begin{array}{l}\text { Church } \\
\text { Attendance }\end{array}$ & 66960 & 3.41 & 1.92 & 1 & 7 \\
\hline $\begin{array}{l}\text { Importance of } \\
\text { Religion }\end{array}$ & 66793 & 2.68 & 1.04 & 1 & 4 \\
\hline Age & 67495 & 46.35 & 17.79 & 14 & 108 \\
\hline $\begin{array}{l}\text { Country-Mean } \\
\text { Importance of } \\
\text { Religion }\end{array}$ & 66786 & 2.68 & 0.52 & 1.53 & 3.75 \\
\hline $\begin{array}{l}\text { GDP per capita in } \\
\text { Mjo USD, log }\end{array}$ & 67286 & 9.73 & 1.05 & 7.43 & 11.67 \\
\hline $\begin{array}{l}\text { Political Stability } \\
\text { and Absence of } \\
\text { violence, Mean } \\
\text { 1996-2008, }\end{array}$ & 67286 & 0.39 & 0.723 & -1.03 & 1.48 \\
\hline Gini Coefficient & 67786 & 32.18 & 4.62 & 24.70 & 43.20 \\
\hline $\begin{array}{l}\text { Net Migration } \\
\text { Rate }\end{array}$ & 67286 & 0.56 & 2.58 & -4.95 & 8.54 \\
\hline $\begin{array}{l}\text { Categorical } \\
\text { Variables }\end{array}$ & Obs. & Percent & & Min. & Max. \\
\hline $\begin{array}{l}\text { "Would not like } \\
\text { as Neighbors: } \\
\text { People of a } \\
\text { different Race" }\end{array}$ & 64997 & 16.0 & & 0 & 1 \\
\hline Catholic & 67286 & 27.0 & & 0 & 1 \\
\hline Protestant & 67286 & 11.0 & & 0 & 1 \\
\hline Orthodox & 67286 & 23.0 & & 0 & 1 \\
\hline Muslim & 67286 & 11.0 & & 0 & 1 \\
\hline $\begin{array}{l}\text { Other } \\
\text { Denomination }\end{array}$ & 67286 & 1.0 & & 0 & 1 \\
\hline
\end{tabular}




$\begin{array}{lllll}\begin{array}{l}\text { Belief: Personal } \\ \text { God }\end{array} & 66909 & 43.0 & 0 & 1 \\ \begin{array}{l}\text { Belief: Spirit/Life } \\ \text { Force }\end{array} & 66909 & 32.0 & 0 & 1 \\ \begin{array}{l}\text { Belief: } \\ \text { Fundamentalism }\end{array} & 66603 & 26.0 & 0 & 1 \\ \begin{array}{l}\text { Tertiary } \\ \text { Education }\end{array} & 67171 & 23.0 & 0 & 1 \\ \begin{array}{l}\text { Sex: Female } \\ \begin{array}{l}\text { Long-Term } \\ \text { Unemployment }\end{array}\end{array} & 67274 & 55.0 & 0 & 1 \\ \begin{array}{l}\text { Right-wing } \\ \text { fing }\end{array} & 25.0 & 15.0 & 0 & 1 \\ \end{array}$

Note: Political Stability = high values indicate high stability, Gini Coefficient $=$ high values indicate high inequality. 
Table 2. Percent racially intolerant among the religious and non-religious across

countries

\begin{tabular}{|c|c|c|c|c|}
\hline \multicolumn{5}{|c|}{ “Would not like as Neighbors: People of a different Race” } \\
\hline & $\begin{array}{l}\text { attends } \\
\text { church at } \\
\text { least } \\
\text { once a } \\
\text { month }\end{array}$ & $\begin{array}{l}\text { attends } \\
\text { church } \\
\text { less than } \\
\text { once a } \\
\text { month }\end{array}$ & $\begin{array}{l}\text { Religion } \\
\text { is } \\
\text { important }\end{array}$ & $\begin{array}{l}\text { Religion } \\
\text { is not } \\
\text { important }\end{array}$ \\
\hline Sweden & 0.0 & 6.3 & 6.4 & 5.3 \\
\hline Iceland & 1.6 & 1.1 & 1.0 & 1.3 \\
\hline Belgium & 3.2 & 6.2 & 4.8 & 5.8 \\
\hline Denmark & 3.9 & 4.1 & 5.2 & 3.7 \\
\hline France & 4.2 & 3.3 & 4.9 & 2.6 \\
\hline Switzerland & 4.5 & 2.5 & 3.0 & 2.9 \\
\hline Great Britain & 4.8 & 5.7 & 4.6 & 6.7 \\
\hline Spain & 5.2 & 3.6 & 5.2 & 3.2 \\
\hline Northern Ireland & 6.2 & 9.1 & 7.7 & 7.6 \\
\hline Germany East & 6.5 & 4.4 & 2.8 & 4.6 \\
\hline Germany West & 6.5 & 3.3 & 4.4 & 3.9 \\
\hline Norway & 7.7 & 5.7 & 5.5 & 4.8 \\
\hline Finland & 8.6 & 8.7 & 7.8 & 9.1 \\
\hline Netherlands & 10 & 9.7 & 11.9 & 10.2 \\
\hline Portugal & 10.1 & 10.3 & 12.5 & 11.3 \\
\hline Hungary & 11.8 & 8.7 & 8.9 & 9.0 \\
\hline Poland & 12.3 & 12.1 & 11.5 & 13.6 \\
\hline Croatia & 12.4 & 12.7 & 12.5 & 12.4 \\
\hline Ireland & 12.5 & 9.8 & 11.3 & 8.7 \\
\hline Greece & 13.1 & 7.5 & 10.8 & 6.1 \\
\hline Montenegro & 13.3 & 12.5 & 13.6 & 9.5 \\
\hline Luxembourg & 13.4 & 12.2 & 14.4 & 10.9 \\
\hline \multicolumn{5}{|l|}{ Bosnia } \\
\hline Herzegovina & 14.6 & 13.6 & 12.7 & 19.6 \\
\hline Ukraine & 14.8 & 7.7 & 8.6 & 11.5 \\
\hline Slovak Republic & 15.3 & 12.9 & 15.7 & 13.0 \\
\hline Italy & 15.6 & 16.0 & 15.4 & 15.3 \\
\hline Latvia & 15.7 & 13.5 & 15.0 & 13.0 \\
\hline \multicolumn{5}{|l|}{ Russian } \\
\hline Federation & 15.9 & 15.5 & 14.4 & 16.5 \\
\hline Austria & 16.9 & 17.7 & 14.4 & 19.6 \\
\hline Belarus & 17.5 & 18.0 & 17.9 & 17.3 \\
\hline Cyprus & 17.9 & 15.3 & 16.3 & 18.8 \\
\hline Bulgaria & 18.4 & 19.9 & 20.8 & 19.7 \\
\hline Lithuania & 18.5 & 12.8 & 18.8 & 11.1 \\
\hline Serbia & 19.7 & 20.0 & 20.0 & 17.4 \\
\hline Romania & 20.4 & 19.9 & 19.9 & 20.5 \\
\hline Czech Republic & 21.1 & 21.8 & 25.1 & 21.2 \\
\hline Moldova & 21.5 & 17.6 & 18.9 & 19.6 \\
\hline Georgia & 22.9 & 22.0 & 22.5 & 17.9 \\
\hline Estonia & 23.7 & 23.0 & 24.9 & 23.5 \\
\hline
\end{tabular}




\begin{tabular}{lllll} 
Macedonia & 24.1 & 19.5 & 20.2 & 24.6 \\
Malta & 25.2 & 22.6 & 24.7 & 26.4 \\
Slovenia & 27.3 & 28.6 & 28.1 & 28.5 \\
Albania & 31.9 & 36.4 & 41.3 & 28.8 \\
Kosovo & 34.1 & 22.1 & 29.1 & 20.4 \\
Azerbaijan & 36.3 & 26.3 & 30.9 & 21.0 \\
Turkey & 45.1 & 40.6 & 42.6 & 30.8 \\
Armenia & 45.2 & 39.9 & 42.9 & 34.6 \\
Northern Cyprus & 54.0 & 59.0 & 54.7 & 56.7 \\
\hline Total & 19.1 & 15.2 & 18.9 & 12.9 \\
\hline
\end{tabular}


Table 3. Binary logistic multilevel models — Religion and racial intolerance

DV: "Would not like as Neighbor: People of a different Race”

\begin{tabular}{|c|c|c|}
\hline & Coef. & S.E. \\
\hline Belief: Personal God & $-0.178 * * *$ & 0.035 \\
\hline Belief: Spirit/Life Force & $-0.329 * * *$ & 0.035 \\
\hline Fundamentalism & $0.300 * * *$ & 0.028 \\
\hline Catholic & 0.036 & 0.045 \\
\hline Protestant & 0.030 & 0.065 \\
\hline Orthodox & 0.085 & 0.045 \\
\hline Muslim & 0.119 & 0.067 \\
\hline Other Denomination & -0.043 & 0.097 \\
\hline Church Attendance & 0.007 & 0.008 \\
\hline Importance of Religion & $0.031^{*}$ & 0.015 \\
\hline Education: Tertiary & $-0.452 * * *$ & 0.037 \\
\hline $\begin{array}{l}\text { Education: Below tertiary, } \\
\text { above primary }\end{array}$ & $-0.192 * * *$ & 0.030 \\
\hline Sex: Female & $-0.086 * * *$ & 0.022 \\
\hline Long-term Unemployment & $0.083^{* *}$ & 0.026 \\
\hline Age & $0.003 * * *$ & 0.000 \\
\hline Right-wing & $0.249 * * *$ & 0.030 \\
\hline $\begin{array}{l}\text { Country-Mean Importance of } \\
\text { Religion }\end{array}$ & $0.415^{*}$ & 0.217 \\
\hline GDP (log) & $-0.416^{*}$ & 0.180 \\
\hline Political Stability Index & 0.438 & 0.288 \\
\hline Gini Coefficient & 0.011 & 0.002 \\
\hline Net Migration rate & -0.063 & 0.048 \\
\hline $\begin{array}{l}\text { Dummy: Azerbaijan, Kosovo, } \\
\text { Macedonia }\end{array}$ & 0.725 & 1.958 \\
\hline Constant & $-0.388 *$ & 0.179 \\
\hline \multicolumn{3}{|l|}{ Random part: } \\
\hline Level-2-Variance & 0.398 & 0.004 \\
\hline Wald-test (overall model) & $31.80 * * *$ & \\
\hline$N$ & 67,786 & \\
\hline
\end{tabular}

${ }^{*} P<0.05 ;{ }^{* *} p<0.01 ;{ }^{* * *} p<0.001$. Note: The Estimates are from the multiply imputed model, based on 30 imputations. 
Table 4. Racial intolerance and the national context - Cross-level interactions

DV: "Would not like as Neighbor: People of a

Coef. S.E. Wald-

different Race"

test

\begin{tabular}{llll}
\hline Country Mean Importance of Religion *Belief: & 0.033 & 0.029 & 0.00
\end{tabular}

Personal God

Country Mean Importance of Religion *Belief: $\quad \begin{array}{lll}-0.001 & 0.039 & 0.78\end{array}$

Spirit/Life Force

$\begin{array}{llll}\text { Country Mean Importance of Religion } & 0.018 & 0.028 & 0.39\end{array}$

*Fundamentalism

Country Mean Importance of $\quad \begin{array}{lll}0.033^{*} & 0.034 & 5.44 *\end{array}$

Religion*Importance of Religion

Country Mean Importance of Religion*Church $\quad 0.005 * \quad 0.001$ 8.5*

Attendance

\begin{tabular}{|c|c|c|c|}
\hline GDP*Belief: Personal God & -0.002 & 0.055 & 1.36 \\
\hline GDP*Belief: Spirit/Life Force & $-0.053^{*}$ & 0.023 & $13.6^{* *}$ \\
\hline GDP*Fundamentalism & $-0.068 *$ & 0.030 & $4.8^{*}$ \\
\hline GDP*Importance of Religion & $-0.066 * * *$ & 0.014 & $6.7^{*}$ \\
\hline GDP*Church Attendance & $-0.029 * *$ & 0.009 & $7.9 *$ \\
\hline $\begin{array}{l}\text { Political Stability 1996-2008, Mean *Belief: } \\
\text { Personal God }\end{array}$ & $-0.090^{*}$ & 0.040 & $5.64^{*}$ \\
\hline $\begin{array}{l}\text { Political Stability 1996-2008, Mean *Belief: } \\
\text { Spirit/Life Force }\end{array}$ & -0.014 & 0.040 & 0.14 \\
\hline $\begin{array}{l}\text { Political Stability 1996-2008, Mean } \\
\text { *Fundamentalism }\end{array}$ & -0.003 & 0.021 & 1.79 \\
\hline $\begin{array}{l}\text { Political Stability 1996-2008, Mean *Importance } \\
\text { of Religion }\end{array}$ & $-0.076 * * *$ & 0.019 & $15.74^{* *}$ \\
\hline $\begin{array}{l}\text { Political Stability 1996-2008, Mean *Church } \\
\text { Attendance }\end{array}$ & $-0.028 * *$ & 0.008 & $10.57 * *$ \\
\hline Gini Coefficient *Belief: Personal God & 0.044 & 0.029 & 2.39 \\
\hline Gini Coefficient *Belief: Spirit/Life Force & -0.001 & 0.028 & 0.14 \\
\hline Gini Coefficient $*$ Fundamentalism & -0.007 & 0.028 & 0.10 \\
\hline
\end{tabular}




\begin{tabular}{llll} 
Gini Coefficient *Importance of Religion & 0.025 & 0.014 & 1.13 \\
Gini Coefficient *Church Attendance & 0.009 & 0.007 & 1.55 \\
\hline Net Migration Rate* Belief: Personal God & -0.007 & 0.009 & 0.64 \\
Net Migration Rate* Belief: Spirit/Life Force & -0.002 & 0.010 & 3.90 \\
Net Migration Rate* Fundamentalism & -0.059 & 0.049 & 4.60 \\
Net Migration Rate* Importance of Religion & $-0.029^{* * *}$ & 0.004 & $32.16^{* * *}$ \\
Net Migration Rate* Church Attendance & -0.002 & 0.002 & 0.83
\end{tabular}

$* P<0.05 ;{ }^{* *} p<0.01 ; * * * p<0.001$. Note: For reasons of space economy this table displays only the coefficients of the cross-level interactions with their standard errors and Wald-tests ( $1 \mathrm{df}$ ) and not the main effects and controls. The cross-level interactions were carried out in the fully controlled multilevel model as displayed in Table 3. 
FIGURE 1. Scatterplot: country percent racially intolerant by country-level religiosity.

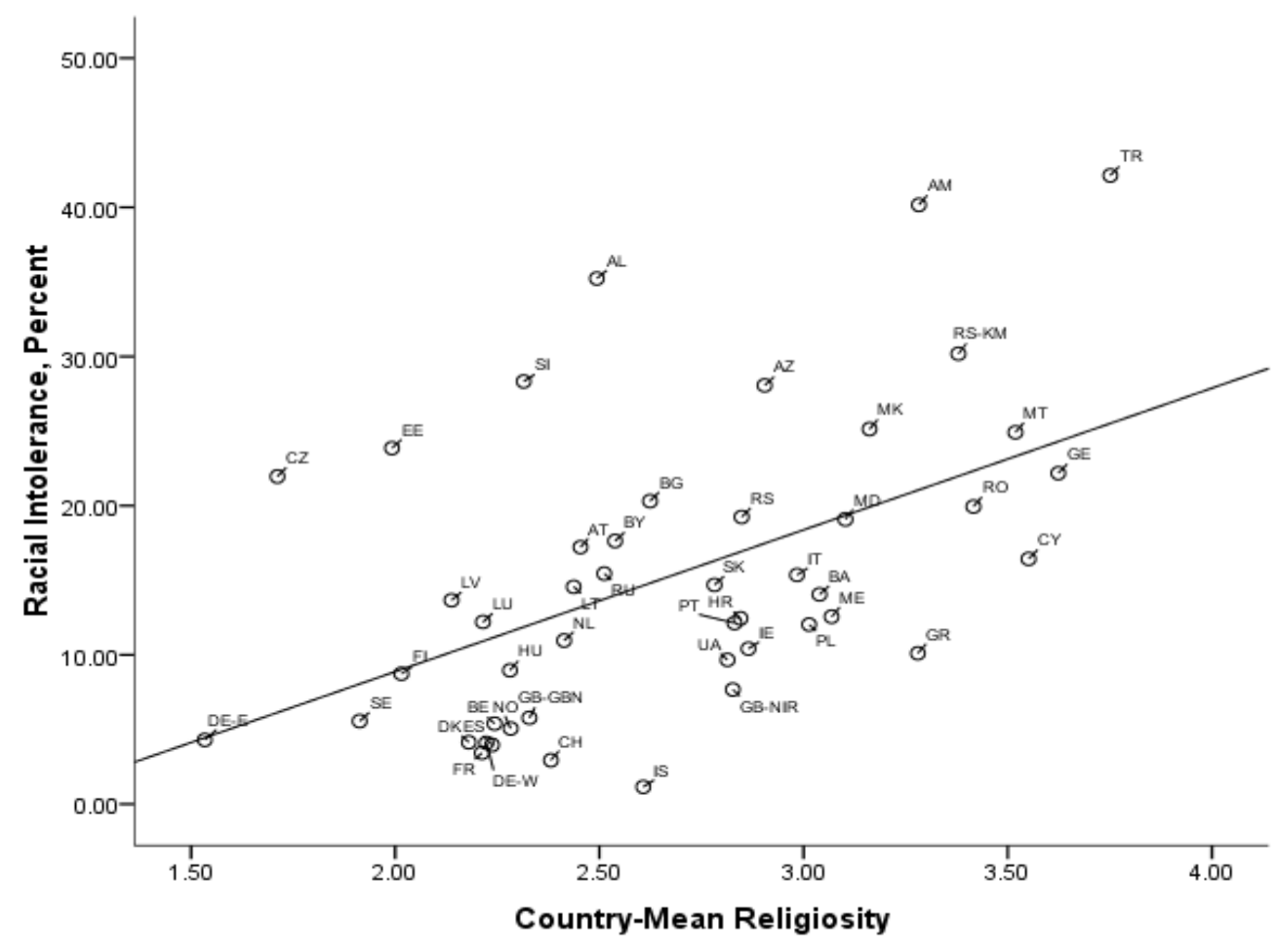




\section{FIGURE 2. Cross-level interactions: Importance of religion and national contexts.}
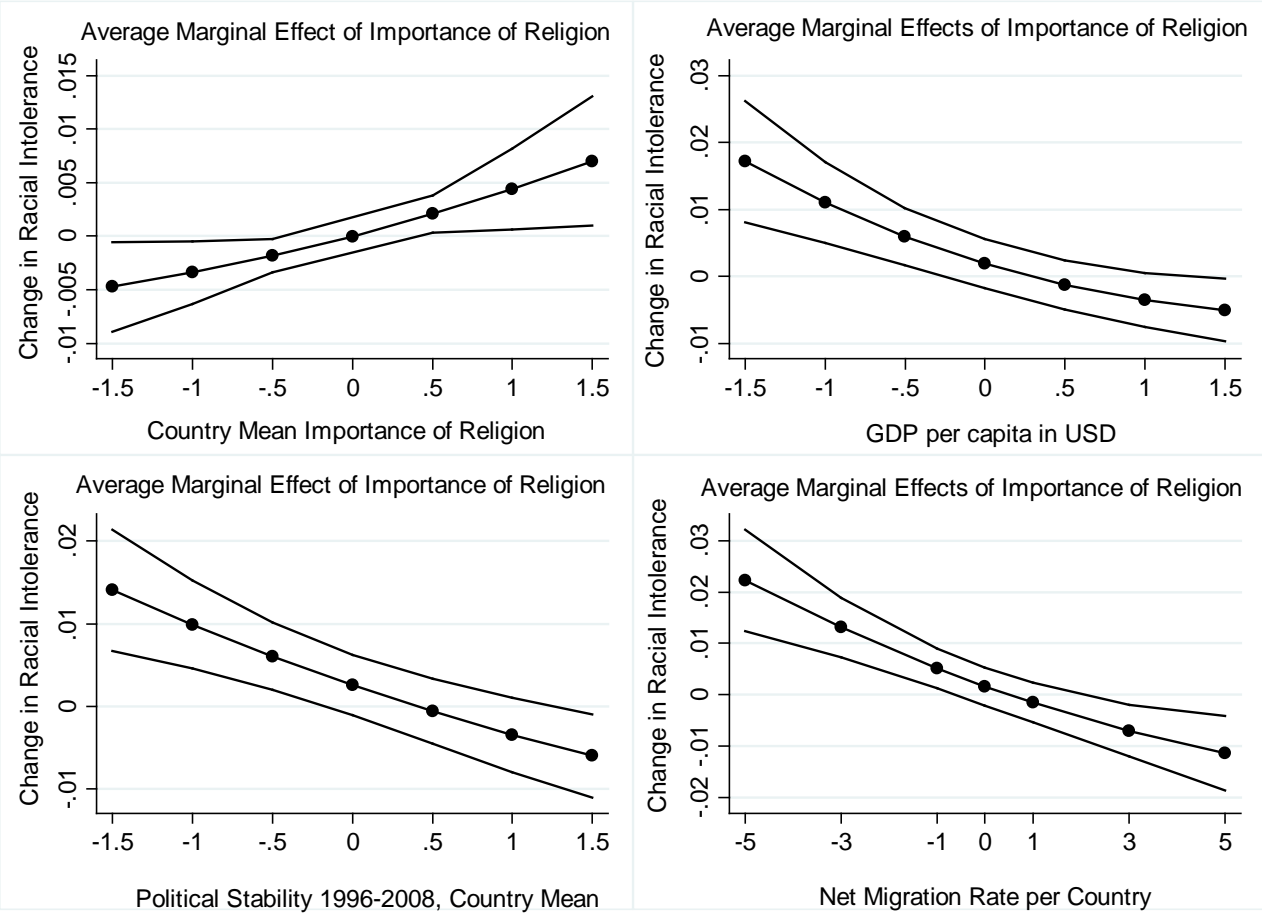

Note: The plots show the coefficient of finding religion important with upper and lower $95 \%$ confidence intervals at each point of the scales of the country-level variables. The country-level variables have been mean-centered. 


\section{Online Appendix}

Table A1. Model fit of multi-group confirmatory factor analysis (MCFA) across 47 countries

\begin{tabular}{|l|l|l|l|l|l|l|l|}
\hline Model & & $X^{2}$ & df & Diff. in $X^{2}$ & CFI & TLI & RMSEA \\
\hline $\begin{array}{l}\text { One-Factor } \\
\text { Model } \\
\text { Ethnic } \\
\text { Intolerance }\end{array}$ & $\begin{array}{l}\text { Scalar } \\
\text { Invariance }\end{array}$ & 11500.258 & 449 & 219.974 & .931 & .958 & .131 \\
\cline { 2 - 8 } & $\begin{array}{l}\text { Partial } \\
\text { Scalar } \\
\text { Invariance a }^{\text {a }}\end{array}$ & 2065.327 & 165 & $\mathrm{P}<0.001$ & .966 & .977 & .091 \\
\cline { 2 - 8 } & $\begin{array}{l}\text { Partial } \\
\text { Scalar } \\
\text { Invariance }^{\text {b }}\end{array}$ & 1431.519 & 161 &. & .976 & .983 & .076 \\
\hline
\end{tabular}

The factor-model included "would not like: people of a different race," "would not like: immigrants," "would not like: Jews." "Would not like Gypsies" and "would not like Christians/Muslims” were included initially, but dropped from the model due to measurement non-invariance after inspection of the item-thresholds and model modification indices across countries. ${ }^{b}$ Partial scalar invariance when excluding Turkey. 
Table A2. Imputation report

Observations

\begin{tabular}{llllc}
\hline Variable & Complete & Incomplete & Imputed & Total \\
\hline $\begin{array}{l}\text { "Would not like as Neighbor: People of a } \\
\text { different Race” }\end{array}$ & 64997 & 2789 & 2789 & 67786 \\
Belief: Personal God & 66909 & 877 & 877 & 67786 \\
Belief: Spirit/Life Force & 66909 & 877 & 877 & 67786 \\
Fundamentalism & 66603 & 1183 & 1183 & 67786 \\
Church Attendance & 66960 & 826 & 826 & 67786 \\
Importance of Religion & 66793 & 993 & 993 & 67786 \\
Sex: female & 67774 & 12 & 12 & 67786 \\
Education: tertiary & 67171 & 615 & 615 & 67786 \\
Education: above primary, below tertiary & 67171 & 615 & 615 & 67786 \\
Right-wing & 62533 & 5253 & 5253 & 67786 \\
Age & 67495 & 291 & 291 & 67786
\end{tabular}

Note: Thirty multiple imputations were carried out using chained equations in STATA. The imputation model accounts for clustering by country. Auxiliary variables: bad health, volunteering. The imputation model includes the interaction terms used in the final models. 
Table A3. Multicollinearity diagnostics

\begin{tabular}{|c|c|c|c|}
\hline Variable & VIF & Tolerance & Squared \\
\hline Catholic & 2.33 & 0.42 & 0.5706 \\
\hline Protestant & 1.62 & 0.61 & 0.3818 \\
\hline Orthodox & 2.57 & 0.38 & 0.6108 \\
\hline Muslim & 2.10 & 0.47 & 0.523 \\
\hline Other Denomination & 1.13 & 0.88 & 0.1159 \\
\hline Church Attendance & 1.80 & 0.55 & 0.4445 \\
\hline Importance of Religion & 2.00 & 0.50 & 0.5005 \\
\hline Belief: Personal God & 2.47 & 0.40 & 0.5945 \\
\hline Belief: Spirit/Life Force & 1.76 & 0.60 & 0.4307 \\
\hline Fundamentalism & 1.31 & 0.76 & 0.2361 \\
\hline Education: tertiary & 1.99 & 0.50 & 0.4971 \\
\hline Education: above primary, below tertiary & 1.97 & 0.51 & 0.4931 \\
\hline Volunteering & 1.09 & 0.92 & 0.0806 \\
\hline Sex: female & 1.04 & 0.96 & 0.0382 \\
\hline Long-term Unemployment & 1.14 & 0.88 & 0.1191 \\
\hline Age & 1.18 & 0.85 & 0.1492 \\
\hline Right-wing & 1.02 & 1.01 & 0.979 \\
\hline Country-Mean importance of Religion & 2.28 & 0.44 & 0.5614 \\
\hline GDP per capita (log) & 4.67 & 0.21 & 0.7857 \\
\hline Gini Coefficient & 1.64 & 0.60 & 0.3907 \\
\hline Political Stability 1996-2008, Mean & 4.07 & 0.24 & 0.7542 \\
\hline Net migration rate & 1.93 & 0.52 & 0.4806 \\
\hline Mean VIF & 1.93 & & \\
\hline
\end{tabular}


